\title{
Dissemination of in-situ management technologies of paddy residue through farm machinery
}

\author{
Maninder Singh Bons* and Ajaib Singh \\ Krishi Vigyan Kendra, Bahowal, Hoshiarpur (Punjab) India \\ (Email: msbons-hsp@pau.edu)
}

\begin{abstract}
Burning of crop residue has acquired very serious dimensions in the recent past. It has adverse effect on soil health, human health and also on the environment. Punjab Agricultural University, Ludhiana has developed and recommended different paddy residue management technologies for the betterment of agricultural community. PAU, Ludhiana, Indian Council of Agricultural Research, New Delhi and Department of Agriculture and Farmers Welfare, Govt. of Punjab have been advocating the non-burning of crop residue to avoid environmental degradation for the benefit of the people and better soil health in campaign mode. Concerted efforts have been made at the district level for creating awareness and managing the problem, through active collaboration of all the concerned departments. Krishi Vigyan Kendra, Hoshiarpur has been conducting awareness programmes and frontline demonstrations on these paddy residue management machineries/strategies in collaboration with Department of Agriculture and Farmers Welfare, Hoshiarpur. To intensify the extension efforts for the in-situ management of paddy residue, Department of Agriculture and Farmers Welfare, Govt. of India, Indian Council of Agricultural Research, New Delhi and ICAR- Agricultural Technology Application Research Institute, Zone-I had allotted a project on promotion on agricultural mechanization for in-situ management of crop residue in the state of Punjab to the KVKs of Punjab. Under this project, KVK, Hoshiarpur had adopted six villages i.e. Todarpur, Pandori Ganga Singh, Kotla, Sakruli, Panjoura and Gujjarpur in the Hoshiarpur district where 93 frontline demonstrations on in-situ paddy residue management farm machinery i.e. happy seeder and paddy straw chopper were conducted on an area of 208 ha during 2018-19. Farmers were satisfied with the performance of wheat crop sown after the use of happy seeder and paddy straw chopper. Apart from frontline demonstrations, other activities like, one Kisan mela, 25 training programmes, 4 farmer-scientist interfaces, 3 field days, 4 school programmes and 1 college programme for mobilization of school and college students on in-situ paddy residue management technologies, were organized. Due to these concerted efforts the area under these technologies in these villages has increased from 80 ha in 2017-18 to 500 ha in 2018-19.
\end{abstract}

Key Words : In-situ management, Crop residue, Happy seeder, Paddy straw chopper

View Point Article : Bons, Maninder Singh and Singh, Ajaib (2020). Dissemination of in-situ management technologies of paddy residue through farm machinery. Internat. J. agric. Sci., 16 (1) : 22-28, DOI:10.15740/HAS/IJAS/16.1/22-28. Copyright@ 2020: Hind AgriHorticultural Society.

Article History : Received : 12.10.2019; Revised : 05.11.2019; Accepted : 06.12.2019

\footnotetext{
* Author for correspondence:
} 